\title{
Effect of Natural Resin on Strength Parameters of Sandy Soil
}

\author{
H. Suha Aksoy and Mesut Gor
}

\begin{abstract}
Nowadays, strength characteristics of soils have more importance due to increasing building loads. In some projects, geotechnical properties of the soils should be improved. Geotechnical engineers generally use waste materials to improve soil properties but most of these materials have toxic substances such as heavy metal slags, fly ash, silica fume and industrial resins.

In this study, the effects of the addition of a plant gum, named as astragalus, grown commonly in Central and East Anatolia, Iran, Iraq, Turkmenistan and Transcaucasia, on the stability and strength parameters of cohessionless soil were investigated. Astragalus is a pure natural and environmental friendly material. Ground water directly affected by soil additives which used for soil improvement.

In this investigation, properties of a cohessionless soil were stabilized by using astragalus. In order to find out which rate of the additive caused maximum strength parameters of the soil samples which prepared by using four different replacement amounts of $0 \%, 3 \%, 5 \%$ and $10 \%$ by weight of soil. Maximum dry densities and optimum moisture contents were determined for each mixture. Strength parameters of each mixture were also determined. According to experimental study, adding 1\% of astragalus content is convenient for sandy soil when considered strength parameters and economical respect of additive material.
\end{abstract}

Index Terms-Natural resin, soil improvement, strength parameters, toxic materials.

\section{INTRODUCTION}

Human beings use soil as building and foundation material to build homes and roads through the ages. Geotechnical properties of an soil can be improved in two ways: compaction and mixing with additive material such as lime, cement, fly ash, natural materials etc.

In this paper, geotechnical properties of an embankment soil were improved. The soil was taken from a commercial sand pit in Elazig City. Effects of a plant gum, named as astragalus, on the strength parameters of the sandy soil were studied. Geotechnical properties of the sandy soil were determined. Maximum dry density and optimum moisture content of the sandy soil also found out. Samples were prepared by using four different replacement amounts of $0 \%$, $1 \%, 3 \%, 5 \%$ and $10 \%$ by weight of soil. All samples were prepared at optimum moisture content. Shear box tests were conducted on these samples.

The existing soil at a construction site cannot always be totally suitable for supporting structures. For this reason

Manuscript received November 11, 2012; revised January 21, 2013.

The authors are with the Civil Engineering Department, Engineering Faculty, Firat University, Elazig, Turkey (e-mail: aksoy.suha@gmail.com; mesutgor@gmail.com). cheap, safe and natural materials should be used for soil improvement. Cement, lime, fly ash, bituminous materials, chlorite, natural or industrial resins can be used as additive materials [1].

Gopal, R., Singh, J. and Das, G. studied on use of a few natural resins as dune sand stabilizer. Guar-gum - a product of Rajasthan desert, Terminalia alata tannins and rosin have proved promising for short-term and emergency use in field. Effect of compaction on strength has also been studied in order to optimize the thickness of stabilized surfaces required for construction of roads arid helipads in sandy areas. Effect of temperature and bacteria on stabilized specimens has also been discussed [2].

Levacic, E. and Bravar, M. determined the properties of a soil sample which mixed with urea formaldehyde resin. Several samples of soil and resin mixed in different ratios were prepared. Investigations of different parameters showed the resin significantly improves geomechanical soil properties. As a result the urea formaldehyde resin applied in the tests can be used for stabilization [3].

Lahalih, S.M., Ahmed, N. have been study on the strength parameters of improved sand dune. Researchers have used chemical resins for the improvement. This chemical resins which consist of melamine, formaldehyde, urea, caustic soda and sulfuric acid. According to the researchers, adding 1\% of resin is suitable for stabilization of the soil [4].

Kavak, A., Gungor, A.G., Avsar, C., Atbas, B., Akyarli, A. carried out lime stabilization on a divided road. Before applications, by obtaining the geotechnical features of soils in the laboratories, necessary lime ratio was determined as $\% 5$ using Atterberg limits and CBR values. Application results were evaluated by sand cone method for relative densities, field CBR and plate loading tests on the field after construction works. At the field CBR tests, while having a value of $11 \%$ before the application, the CBR value reached to $48 \%$ and $56 \%$ after the lime stabilization and at the same tests that were performed 28 days later it was calculated as $117 \%$. After examining the plate loading tests, the effect of the lime stabilization was seen much more clearly. In the plate loading tests, permanent deformation values decreased to $1.6 \mathrm{~mm}$ from $22.2 \mathrm{~mm}$. It was also observed that the modulus of subgrade reaction could be up to ten times greater than those of unstabilized soil [5].

Aksoy, H.S., Gor, M. studied on sand dunes properties are stabilized by using Portland cement, fly ash and silica fume. In order to find out which additive caused maximum dry density, soil samples were prepared by using four different replacement amounts of $0 \%, 3 \%, 5 \%$ and $10 \%$ by weight of soil. Maximum dry densities and optimum moisture contents were determined for all mixtures. It is concluded that dune samples have adequate density when compacted with $10 \%$ 
silica fume [6].

\section{MATERIALS AND Methods}

Silty sand soil, provided from sand pit at in Elazig city, was used for filling material in the tests. Soil properties were given in Table I. Particle size distribution curve is given in Fig. 1. After the sieve analysis and hydrometer tests, gravel, sand, silt and clay ratio of soil was determined as $2.5 \%$, $85.5 \%, 10.0 \%$ and $2.0 \%$, respectively. Thus, it was determined that this soil is well graded silty sand (SW-SM).

TABLE.I: PROPERTIES OF THE SOIL.

\begin{tabular}{ll}
\hline \hline Specific Gravity & 2.67 \\
Fines Content (\%) & 12.0 \\
Optimum Moisture Content (\%) & 12.0 \\
Maximum Dry Density $\left(\mathrm{Mg} / \mathrm{m}^{3}\right)$ & 1.93 \\
Angle of Internal Friction (degree) & 41.5 \\
Cohesion $\left(\mathrm{kN} / \mathrm{m}^{2}\right)$ & 26.0 \\
\hline \hline
\end{tabular}

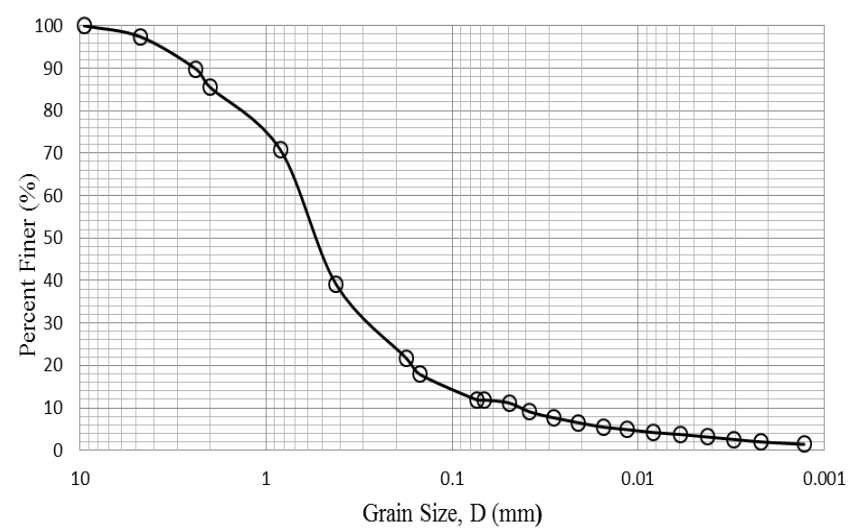

Fig. 1. Particle size distribution curve.

Natural resin, named as astragalus was used as additive material for the filling material [7]. Astragalus material (Fig. 2.a,b) was granulated. After this process, this material was sieved with $0.42 \mathrm{~mm}$ (No.40) sieve and $1 \%, 3 \%, 5 \%$ and $10 \%$ percentage by weight was added to the soil. Proctor tests were performed on these samples.

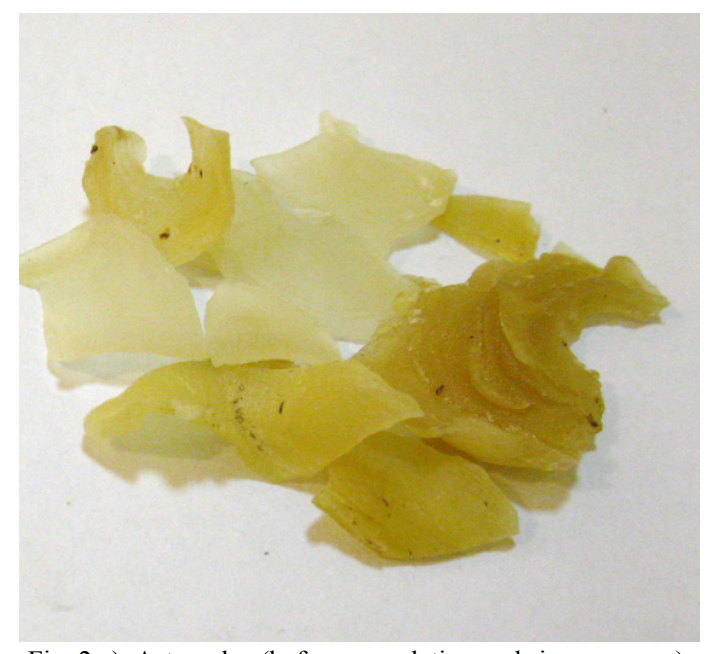

Fig. 2 a). Astragalus (before granulation and sieve process).

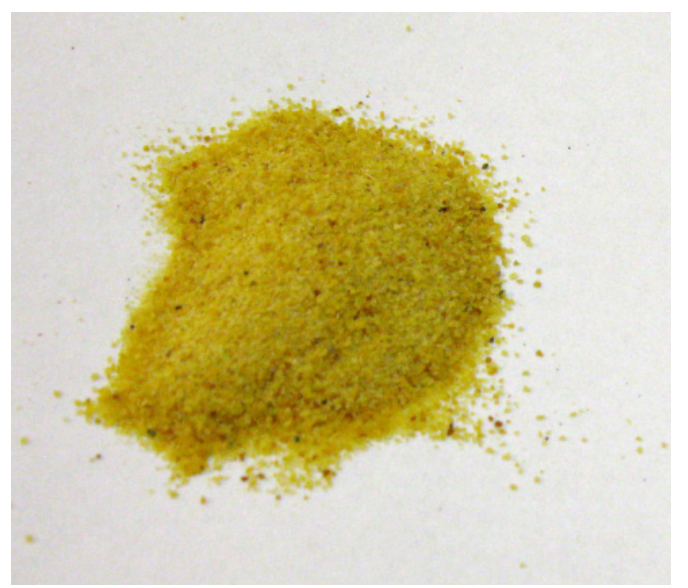

Fig. 2. b) Astragalus (after granulation and sieve process).

\section{RESUlTS AND DISCUSSION}

Dry density and optimum moisture content values of specimen which contained astragalus by weight $0 \%, 1 \%, 3 \%$, $5 \%$ and $10 \%$ are shown in Table II. Obtained results are given in Fig. 3-5.

TABLE II: RESULTS OF THE PROCTORTESTS.

\begin{tabular}{ccc}
\hline $\begin{array}{c}\text { Resin (by weight) } \\
(\%)\end{array}$ & $\begin{array}{r}\text { Dry density } \\
\left(\mathrm{Mg} / \mathrm{m}^{3}\right)\end{array}$ & $\begin{array}{c}\text { Optimum Moisture Content } \\
(\%)\end{array}$ \\
\hline $0 \%$ & 1.93 & 12 \\
$1 \%$ & 1.82 & 14.5 \\
$3 \%$ & 1.72 & 16.5 \\
$5 \%$ & 1.62 & 17 \\
$10 \%$ & 1.49 & 19 \\
\hline \hline
\end{tabular}

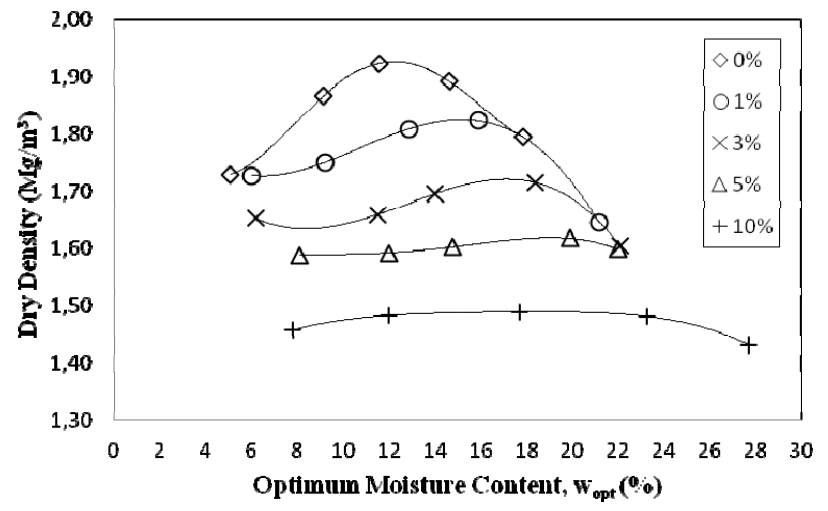

Fig. 3. Results of the proctor tests

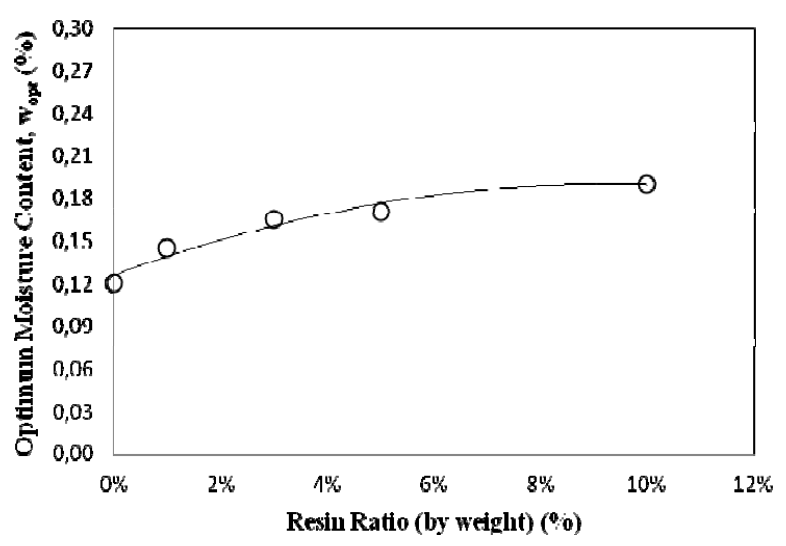

Fig. 4. Resin ratio vs. optimum moisture content. 


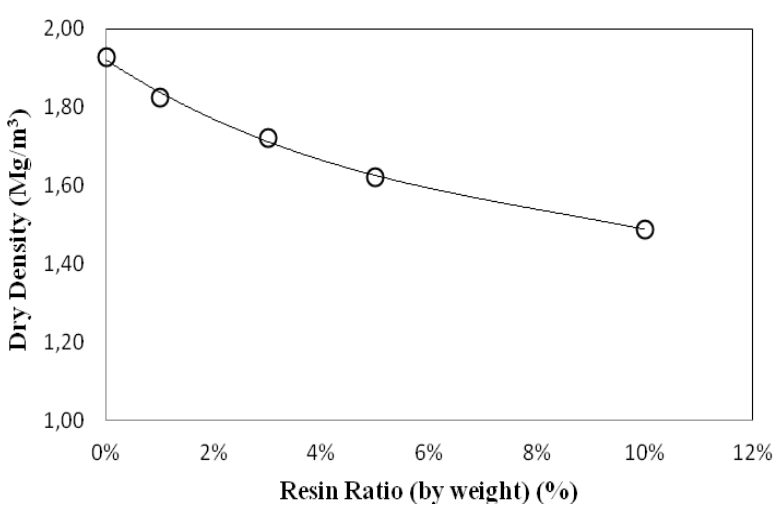

Fig. 5. Resin ratio vs. dry density.

Samples which contain $0 \%, 1 \%, 3 \%, 5 \%$ and $10 \%$ astragalus, are prepared at proctor density. Shear box tests were performed at constant rate of $0.5 \mathrm{~mm} / \mathrm{min}$. Shear box test results of these samples are given Table 3 . Picture of the sample after shear box test, changes of angle of internal friction and cohesion are given in Fig. 6-8, respectively.

TABLE III: SHEAR BOX TEST RESULTS

\begin{tabular}{ccc}
\hline \hline $\begin{array}{c}\text { Resin (by weight) } \\
(\%)\end{array}$ & $\begin{array}{c}\text { Angle of internal friction } \\
(\text { degree })\end{array}$ & $\begin{array}{c}\text { Cohesion } \\
\left(\mathrm{kN} / \mathrm{m}^{2}\right)\end{array}$ \\
\hline$\% 0$ & 41.5 & 26.0 \\
$\% 1$ & 37.0 & 38.0 \\
$\% 3$ & 20.0 & 48.5 \\
$\% 5$ & 18.5 & 52.5 \\
$\% 10$ & 20.5 & 35.5 \\
\hline \hline
\end{tabular}

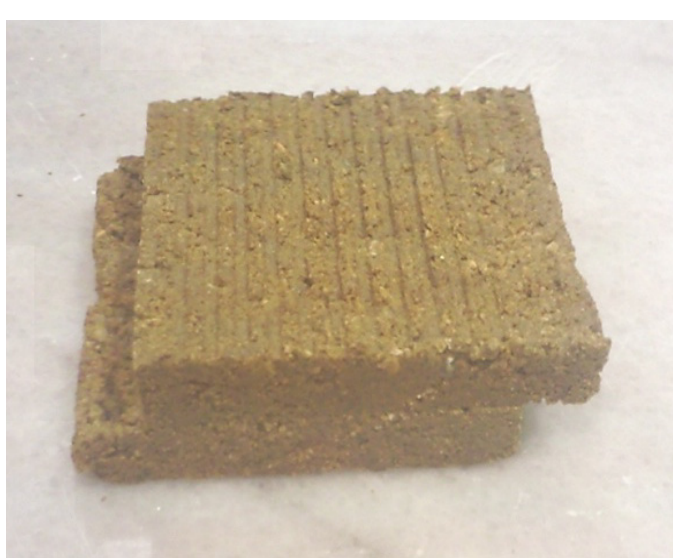

Fig. 6. Test sample after shear box test.

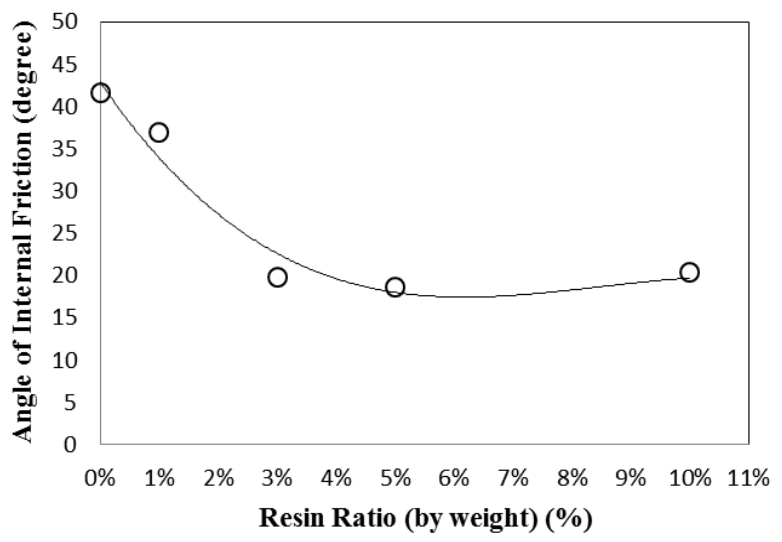

Fig. 7. Resin ratio vs. angle of internal friction.

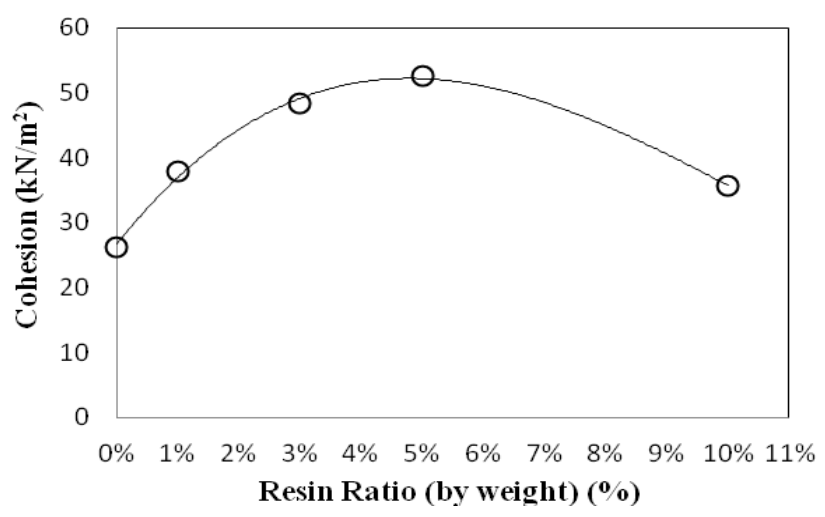

Fig. 8. Resin ratio vs. cohesion values.

\section{CONCLUSIONS AND SUGgesting}

Astragalus is a environmental friendly, commercial product which can use as a additive material in small percentage in soil. Astragalus has not any toxic effect on ground water.

Adding increasing amount of astragalus gets higher optimum moisture content. For instance, adding 5\% of astragalus by weight increased the optimum moisture content from $12 \%$ to $17 \%$ while compared with $0 \%$ of astragalus amount. Furthermore, adding $5 \%$ of astragalus to soil tent to decrease the density from $1.93 \mathrm{Mg} / \mathrm{m}^{3}$ to $1.62 \mathrm{Mg} / \mathrm{m}^{3}$.

It was seen that increasing of astragalus content decreased the internal friction angle on the contrary increasing of astragalus amount supplied higher value of cohesion. For instance, $5 \%$ of astragalus tent to decrease the internal friction angle from $41.5^{\circ}$ to $18.5^{\circ}$ but gets higher value as $100 \%$ from $26 \mathrm{kN} / \mathrm{m}^{2}$ to $52.5 \mathrm{kN} / \mathrm{m}^{2}$ on behalf of cohesion while compared with $0 \%$ of astragalus content. Although $5 \%$ of astragalus additive got maximum value of cohesion, it was seen that internal friction angle was sharply decreased. The decrease of internal friction angle and increasing of cohesion exposed the properties of soil behavior like cohesive soil. The sample without astragalus had the internal friction angle 41.5 ( $0 \%$ of astragalus content) then adding $1 \%$ of astragalus decreased the $11 \%$ of amount then obtained the internal friction angle value $37^{\circ}$. Besides to this, cohesion value was determined $26 \mathrm{kN} / \mathrm{m}^{2}$ without astragalus. After adding $1 \%$ of astragalus, cohesion parameter was increased $45 \%$ ratio and found to be $38 \mathrm{kN} / \mathrm{m}^{2}$.

Increasing amount of astragalus caused strength degradation of the soil. It was concluded that adding $1 \%$ of astragalus content is suitable for sandy soil when considered to strength parameters and economical respect of additive material.

\section{REFERENCES}

[1] J. K. Mitchell, "Soil Improvement, (State of the Art Report)," in Proc. X. Soil Mechanics and Foundation Eng. Conference, Stockholm, Sweden, 1981.

[2] R. Gopal, J. Singh, and G. Das, "Chemical Stabilization of Sand Comparative Studies On Urea-Formaldehyde Resins As Dune Sand Stabilizer and Effect Of Compaction On Strength (Part IV)," Transactions of Indian Society of Desert Tech. and University Centre of Desert Studies, Indian Society of Desert Technology, Jodhpur, India, vol. 8 no. 2 , pp.13-19, 1983. 
[3] E. Levacic and M. Bravar, "Soil Stabilization by Means of Lendur EH Ureaformaldehyde," Rudarsko Geolosko Naftni Zbornik. vol.2, pp 137-143, 1990.

[4] S. M. Lahalih and N. Ahmed, "Effect of new soil stabilizers on the compressive strength of dune sand," Construction and Building Materials, 12 pp. 321-328, 1998.

[5] A. Kavak, A.G. Gungor, C. Avsar, B. Atbas, and A. Akyarli, "A Lime Stabilization Application on a Divided Road Project," The 12th National Soil Mechanics and Foundation Engineering Congress, Selçuk University, Konya, 16-17 October 2008, pp. 659-668, Konya, Turkey [in Turkish with English Summary].

[6] H. S. Aksoy and M. Gor, "Stabilization of dune by using various materials," 4th Geotechnical Symposium, December 1-2, Cukurova University, Adana, Turkey, 1-2 December 2011, pp. 622-628, [in Turkish with English Summary].

[7] N. Kuloglu, "Effect of Astragalus on Characteristics of Asphalt Concrete," Journal of Materials in Civil Engineering, ASCE. vol. 11, no. 4, pp 283 - 286, 1999.

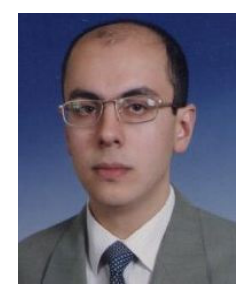

Dr. H. Suha Aksoy was born at 1970 in Elazig city (Turkey). He is working as assistant professor in Firat University Elazig-Turkey. He graduated Istanbul Technical University Civil Engineering Dept. at 1992. In 1995 he started to work as a research assistant at Firat University .He graduated MSc at 1996. He earn $\mathrm{PhD}$ degree at 2004 from Graduate School of Science Engineering and Technology of Istanbul Technical University.

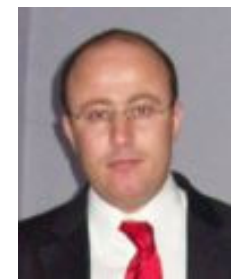

Mesut Gor was born at 1983 in Hakkari city (Turkey). $\mathrm{He}$ is working as research assistant in Firat University Elazig-Turkey since 2009. He graduated Firat University Civil Engineering Dept. at 2005.He graduated MSc at 2011. He continues his PhD study at Graduate School of Science Engineering and Technology of Firat University. 